medRxiv preprint doi: https://doi.org/10.1101/2021.06.22.21259349; this version posted June 25, 2021. The copyright holder for this preprint (which was not certified by peer review) is the author/funder, who has granted medRxiv a license to display the preprint in perpetuity.

It is made available under a CC-BY 4.0 International license .

\title{
Inflection in prevalence of SARS-CoV-2 infections missing the N501Y mutation as a marker of rapid Delta (B.1.617.2) lineage expansion in Ontario, Canada
}

Kevin A. Brown, PhD, Eugene Joh, MPH, Sarah A. Buchan, PhD, Nick Daneman, MD MSc, Sharmistha Mishra MD PhD, Samir Patel, PhD, Troy Day, PhD

\author{
Author Affiliations \\ Public Health Ontario, Canada (Brown, Buchan, Daneman, Joh, Patel) \\ Department of Medicine, University of Toronto, Canada (Mishra) \\ Queens University, Kingston, Canada (Day)
}

Version date: June 22, 2021

\begin{abstract}
Background: The severe acute respiratory syndrome coronavirus 2 (SARS-CoV-2) Delta lineage (B.1.617.2) was implicated in the SARS-CoV-2 surge in India. We sought to describe the rapid expansion of the Delta lineage in Ontario, Canada (population 15 million) using mutation profile information and confirmatory whole genome sequencing. Methods: All laboratory-confirmed SARS-CoV-2 cases reported to Public Health Ontario between April $1^{\text {st }}$ and June $12^{\text {th }} 2021$, with cycle threshold values $\leq 35$, were eligible for screening for the N501Y and the E484K mutations. We classified cases via mutation screening as: (1) N501Y-/E484K- (wild-type/Delta), (2) Alpha (N501Y+/E484K-), (3) Beta/Gamma (N501Y+/E484K+), or (4) N501Y-/E484K+ (predominantly B.1.525, and B.1.1.318). Results: The N501Y-/E484K- mutation profile went from having a $29 \%$ transmission deficit relative to Alpha (relative $\mathrm{R}_{e}=0.71,95 \% \mathrm{Cl}: 0.64,0.77$ ) on April $1^{\text {st }}$ to having a $50 \%$ transmission advantage on June $12^{\text {th }}$ (relative $R_{e}=1.50,95 \% \mathrm{Cl}: 1.31,1.71$ ). Whole genome sequencing of N501Y-/E484K- cases ( $N=583$ ) confirmed that the pattern of increasing relative reproduction number coincided with the replacement of wild-type with Delta variant (from 2.2\% in early April, to $83 \%$ in late May). Discussion: Delta is rapidly overtaking other SARSCoV-2 variants in Ontario, and has a substantial transmission advantage. An inflection in the proportion of cases missing the N501Y mutation from rapidly decreasing to rapidly increasing, ${ }^{3}$ may be an early warning signal for Delta lineage expansion.
\end{abstract}

\section{Background}

The severe acute respiratory syndrome coronavirus 2 (SARS-CoV-2) Delta lineage (B.1.617.2) was implicated in a devastating SARS-CoV-2 surge in India, and subsequently with increasing rates in the United Kingdom. ${ }^{1}$ The Delta variant lacks the N501Y mutation (possessed by Alpha, Beta and Gamma) and also lacks the vaccine escape mutation E484K (possessed by Beta and Gamma). We use mutation profile information and confirmatory whole genome sequencing to describe the rapid expansion of the Delta lineage in Ontario, Canada (population 15 million) during a period of increasing vaccination (first dose coverage: $13.9 \%$ on April $1^{\text {st }}, 63.4 \%$ on June $12^{\text {th }}$ ), and estimate the relative transmissibility of the Delta variant. ${ }^{3}$

NOTE: This preprint reports new research that has not been certified by peer review and should not be used to guide clinical practice. 
medRxiv preprint doi: https://doi.org/10.1101/2021.06.22.21259349; this version posted June 25, 2021. The copyright holder for this preprint (which was not certified by peer review) is the author/funder, who has granted medRxiv a license to display the preprint in perpetuity.

It is made available under a CC-BY 4.0 International license .

\section{Methods}

All laboratory-confirmed SARS-CoV-2 cases reported to Public Health Ontario between April $1^{\text {st }}$ and June $12^{\text {th }}$ 2021 , with cycle threshold values $\leq 35$, were eligible for N501Y and the E484K mutation screening. We classified cases as: (1) N501Y-/E484K- (wild-type/Delta), (2) Alpha (N501Y+/E484K-), (3) Beta/Gamma (N501Y+/E484K+), or (4) N501Y-/E484K+ (predominantly B.1.525, and B.1.1.318). ${ }^{4}$ To adjust for daily differences in the proportion that received mutation screening, we multiplied the proportion of each profile among those screened, by the total number of cases.

We modeled the daily count of each mutation profile using a count quasi-Poisson regression with the date modeled as a flexible spline (weekly knots) and an interaction term between date and each mutation profile. Daily growth, and the daily proportion of N501Y-/E484K- isolates were derived from this model. Daily growth was translated to a reproduction number $\left(R_{e}\right)$, assuming a generation interval of 5.2 days. ${ }^{5}$

Because initial confirmed cases of Delta in Ontario were concentrated in the municipality of Brampton, we also stratified analyses across the Greater Toronto Area's 3 largest municipalities (Toronto [pop. 3,100,000], Mississauga [pop. 900,000], Brampton [pop. 600,000]). Confirmatory whole genome sequencing on a weekly provincial sample of N501Y-/E484K- isolates was used to estimate the proportion that were Delta.

\section{Results}

In total, 185,085 SARS-CoV-2 cases were identified and 153,998 (83.2\%) received mutation screening, of which 81.1\% were Alpha, 9.6\% were N501Y-/E484K-, 5.7\% were Beta/Gamma, and 3.6\% were N501Y-/E484K+. During the period of rapidly increasing vaccination, the estimated reproduction number of Alpha declined from 1.20 to 0.62 (Figure 1), while that of N501Y-/E484K- increased slightly from 0.85 to 0.93 . As such N501Y-/E484K- went from having a $29 \%$ transmission deficit relative to Alpha (relative $R_{e}=0.71,95 \% \mathrm{Cl}: 0.64,0.77$ ) on April $1^{\text {st }}$ to having a $50 \%$ transmission advantage on June $12^{\text {th }}$ (relative $\mathrm{R}_{\mathrm{e}}=1.50,95 \% \mathrm{Cl}: 1.31,1.71$ ).

We observed an inflection from a decreasing trend in the proportion of N501Y-/E484K- before April 28, to an increasing trend afterwards (Figure 2A). SARS-CoV-2 cases in the municipality of Brampton (Figure 2B) experienced this inflection first (April 17). Ontario-wide whole genome sequencing on N501Y-/E484K- samples $(\mathrm{N}=538)$ revealed an increase in the proportion that were Delta (from 2/87 [2.2\%] preceding April 4th, to 10/12 [83\%] in the last week of May); in the week of the inflection approximately half of N501Y-/E484K- samples were Delta $(53.9 \% ; 41 / 76)$.

\section{Discussion}

This study identified a rapid increase in the proportion of SARS-CoV-2 cases with the N501Y-/E484K- mutation profile in Ontario, demonstrating that Delta was rapidly overtaking the Alpha variant and is $50 \%$ more transmissible. Our analyses are consistent with estimates of a $64 \%$ secondary attack rate advantage over the Alpha lineage from the United Kingdom. ${ }^{6}$ Limitations include potentially non-representative sampling for whole genome sequencing. For countries once dominated by Alpha, Beta, or Gamma lineages, an inflection in the proportion of cases missing the N501Y mutation from rapidly decreasing to rapidly increasing, ${ }^{3}$ may be an early warning signal for Delta lineage expansion. 
medRxiv preprint doi: https://doi.org/10.1101/2021.06.22.21259349; this version posted June 25, 2021. The copyright holder for this preprint (which was not certified by peer review) is the author/funder, who has granted medRxiv a license to display the preprint in perpetuity.

It is made available under a CC-BY 4.0 International license.

\section{Acknowledgements}

The authors wish to thank Kirby Cronin for assistance with retrieving and interpreting confirmatory whole genome sequencing data.

\section{References}

1. Torjesen I. Covid-19: Delta variant is now UK's most dominant strain and spreading through schools. $B M J$. Published online June 4, 2021:n1445. doi:10.1136/bmj.n1445

2. Surveillance Report - COVID-19 Vaccine Uptake and Program Impact in Ontario: December 14, 2020 to June 05, 2021. Public Health Ontario; 2021:26. https://www.publichealthontario.ca//media/documents/ncov/epi/covid-19-vaccine-uptake-ontario-epi-summary.pdf

3. Brown KA, Gubbay J, Hopkins J, et al. S-Gene Target Failure as a Marker of Variant B.1.1.7 Among SARS-CoV2 Isolates in the Greater Toronto Area, December 2020 to March 2021. JAMA. 2021;325(20):2115.

doi:10.1001/jama.2021.5607

4. SARS-CoV-2 Whole Genome Sequencing in Ontario, May 31, 2021. Public Health Ontario; 2021:10. https://www.publichealthontario.ca/-/media/documents/ncov/epi/covid-19-sars-cov2-whole-genomesequencing-epi-summary.pdf

5. Ganyani T, Kremer C, Chen D, et al. Estimating the generation interval for coronavirus disease (COVID-19) based on symptom onset data, March 2020. Eurosurveillance. 2020;25(17). doi:10.2807/1560-

7917.ES.2020.25.17.2000257

6. SARS-CoV-2 Variants of Concern and Variants under Investigation in England: Technical Briefing 14. Public Health England; 2021:66.

https://assets.publishing.service.gov.uk/government/uploads/system/uploads/attachment_data/file/99134 3/Variants_of_Concern_VOC_Technical_Briefing_14.pdf 
medRxiv preprint doi: https://doi.org/10.1101/2021.06.22.21259349; this version posted June 25, 2021. The copyright holder for this preprint (which was not certified by peer review) is the author/funder, who has granted medRxiv a license to display the preprint in perpetuity.

It is made available under a CC-BY 4.0 International license.

\section{Tables and Figures}

Figure 1. Estimation of the incidence (left panel) and reproduction number (right panel) of mutation profiles in Ontario. Relative to Alpha (red), the reproduction number of the N501Y-/E484K- mutation profile (purple) went from $29 \%$ lower than Alpha lineage to $50 \%$ higher at the end of the period.

A

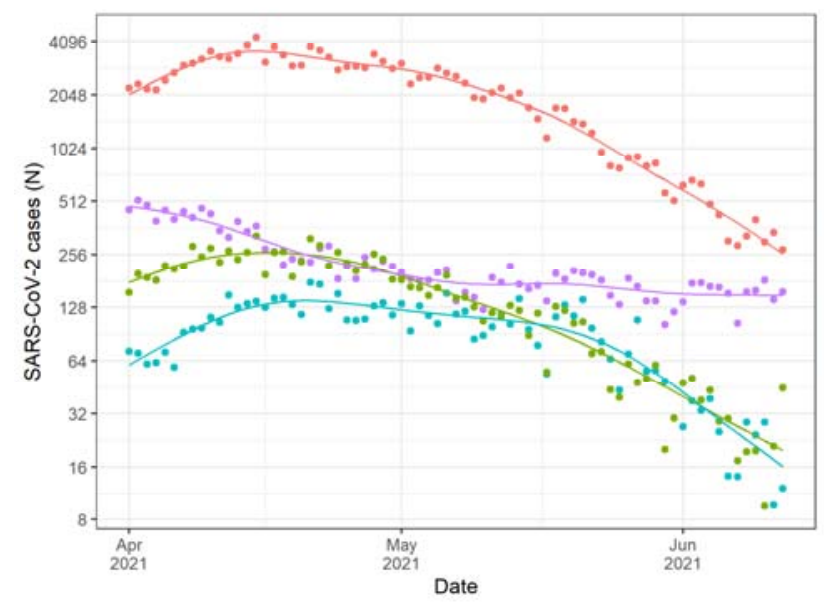

B

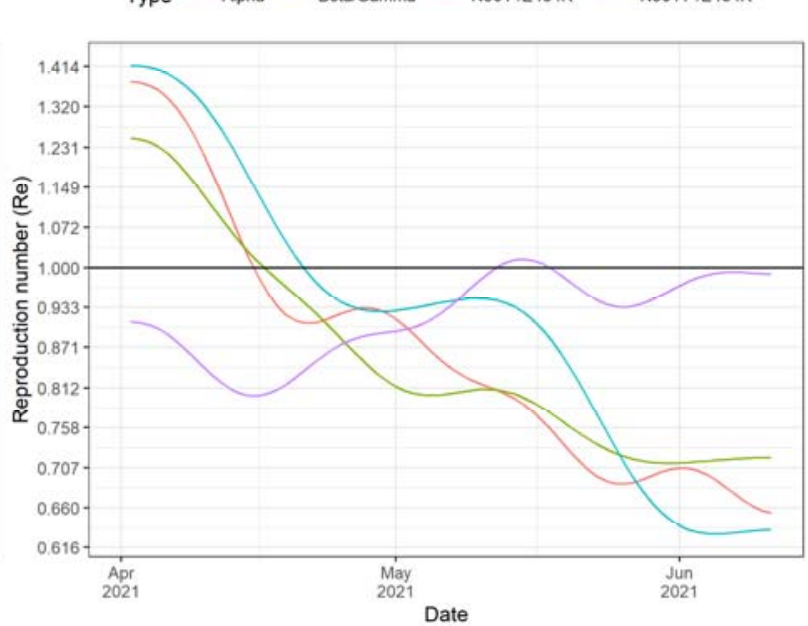

Figure 2. Proportion of SARS-CoV-2 cases with the N501Y-/E484K- mutation profile in Ontario (left panel). We observed an inflection from a rapid decrease in the proportion of N501Y-/E484K- lineages to a rapid increase on April 28. At the end of the study period on June $12^{\text {th }}, \mathrm{N} 501 \mathrm{Y}-/ \mathrm{E} 484 \mathrm{~K}$ - profile cases represented $34 \%$ of SARS-CoV2 cases in Ontario. SARS-CoV-2 cases in the municipality of Brampton (Figure 2B) experienced this change first (April 17) followed by Mississauga (April 24) and then Toronto (May 7).

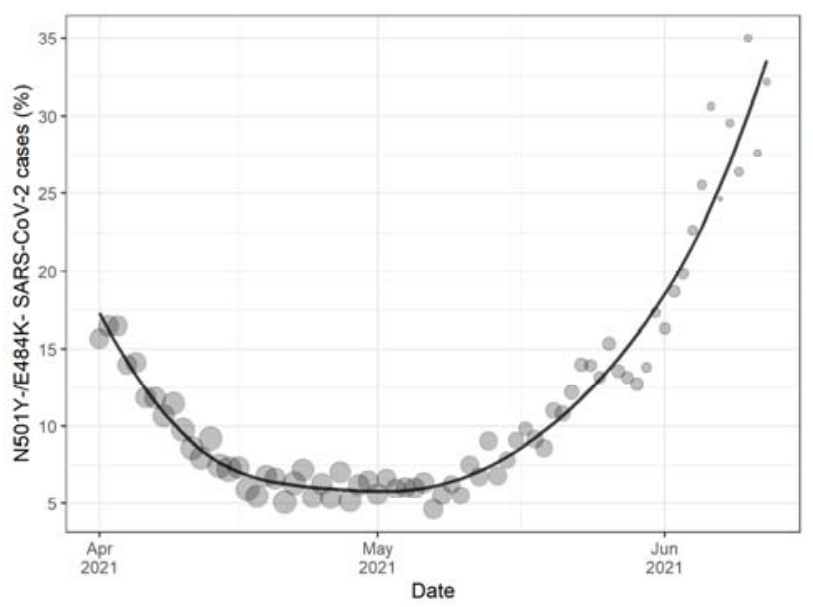

B

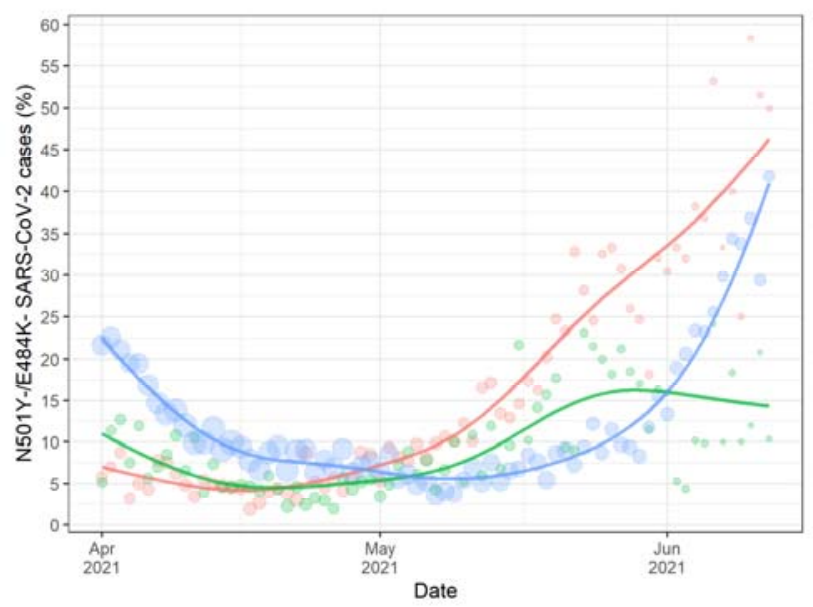

